\title{
辠丸腫瘍の後腹膜リンパ節廓清における射精障害の防止について
}

\author{
東京医科歯科大学医学部泌尿器科学教室 \\ 木原 和徳 福井巌大島 博幸 \\ 埼玉県立がんセンター泌尿器科 \\ 田 利 清 信 \\ 関東中央病院泌尿器科 \\ 岡 \\ 薫
}

\section{A STUDY OF PREVENTION OF EJACULATORY DISTURBANCE AFTER RETROPERITONEAL LYMPH NODE DISSECTION FOR THE TESTICULAR TUMOR}

\author{
Kazunori Kihara ${ }^{11}$, Iwao Fukui ${ }^{11}$, Kiyonobu Tari²), \\ Kaoru $\mathrm{Oka}^{3)}$ and Hiroyuki Oshima ${ }^{1)}$ \\ Department of Urology, School of Medicine, Tokyo Medical and Dental University'), Saitama \\ Prefectural Cancer Center Hospital ${ }^{2}$, and Kanto Chuo Hospital ${ }^{3)}$
}

Forty-five patients with testicular tumor received palliative retroperitoneal lymph node dissection and chemotherapy, and their prognosis and ejaculatory problems such as loss of emission and retrograde ejaculation were evaluated. In these patients, lymph node dissection was limited to the metastatic nodes and/or nodes suspected metastatic including surrounding fatty tissues. Chemotherapy was done prior to and/or following dissection using cis-diamminedichloroplatinum, vinblastine, bleomycin and peplomycin. Ejaculatory function could be evaluated in 36 patients. Nine patients were excluded because their postoperative ejaculatory function was unknown.

A case of suprahilar dissection and 23 of 24 cases dissected from the renal pedicle to the root of the inferior mesenteric artery presented seminal ejaculation. Bilateral dissection from the renal pedicle to the common iliac artery for 7 patients resulted in dry ejaculation in 5 and partial ejaculation in 2 , while ejaculation was observed in all of 4 patients who recieved unilateral dissection of the same area. Four of these patients were examined and three had retrograde ejaculation.

Sympathetic fibers reach the superior hypogastric plexus via the anterior aortic area and via the bilateral sympathetic cords. The present finding indicates: 1) Ejaculatory function is not influenced by injury of sympathetic fibers at the anterior aortic area superior to the root of the inferior mesenteric artery. 2) Sympathetic fibers regulating the internal urethral sphincter appear to enter the superior hypogastric plexus from the bilateral sympathetic cords via the lateral wall of the aorta between the root of the inferior mesenteric artery and the bifurcation but not via the anterior wall of the aortic area. Bilateral injury of these lateral fibers results in retrograde ejaculation. To preserve the above lateral fibers, big bundle of the superior hypogastric plexus should be identified at the aortic bifurcation and then the lateral fibers can be recognized as fine neurofibers connected to the above plexus. 3) Seminal emission was preserved in the patients whose bilateral sympathetic cords appeared to be intact in spite of radical dissection.

Of 31 patients with metastases, 26 were alive with no evidence of disease, one alive with disease and 4 were dead. Of 18 patients with lymph node metastases only, followed for more than 2 years, 17 are alive with no evidence of disease.

In view of recent progress in cancer chemotherapy, dissected area should be minimized to preserve as many sympathetic fibers as possible, which prevents ejaculatory disturbance of young males. 
要旨：化学療法を併用して後腹膜の限局廓清を行なった鋅丸腫瘍患者 45 症例について，予後と射精障害 を検討した。限局廓清の範囲は転移のあるリンパ節もしくは転移が疑われるリンパ節および周囲脂肪組 織である. 化学療法は cis-diamminedichloroplatinum, vinblastine, bleomycin, peplomycin を用いた。 射精機能は，術後の射精機能の不明な 9 例を除く 36 例で評価した。㹂門部より上部を廓清した 1 例およ び腎茎部から下腸間膜動脈起始部まで廓清した 24 例中 23 例では, 射精が認められた。腎茎部から総腸骨 動脈をで搼清した 7 例のらち 5 例は, dry ejaculation であった。一方同部を片側廓清した 4 例全例に射 精が認められた。この 7 例の内 4 例で逆行性射精の有無を調べ， 3 例に認められた。内尿道口閉鎖に関 与する側方線維は両側の交感神経幹から出て大動脈側壁を走り，上下腹神経叢に合流するが，逆行性射 精を防ぐためには，この側方線維を少なくとも片側は温存すること，emission を保つためには両側交感 神経幹を温存することが肝要である，側方線維の温存には大動脈分岐部で上下腹神経叢の太い神経束を 出し，次いでこれに入る側方線維を剥離する方法が良い， 2 年以上経過観察した，リンパ節転移のみ有 した18例のうち17例は癌なしで生存している，化学療法が著明な奏効を示す今日，廓清範囲をできるだ け縮小するとともに神経の温存を意図した廓清を行ない，青壮年男子の射精機能保存を図るべきであろ 5 .

\section{緒 言}

後腹膜リンパ節廓清術は辠丸腫瘍の主要な治療法の 1 つとされ，これまで後腹膜に転移のある症例，ある いは転移が疑われる症例, 除辠後も腫瘍マーカーが陽 性である症例等に広く行なわれてきた。この廓清の手 術手技はリンパ節への到達経路，廓清操作など， ほぼ 確立されており，その目的とするところは腫瘍細胞を 完全に除去すること，すなわち血管を残して動静脈周 囲の組織を腎門部上方から腸骨血管部に至るまで全て 摘除することであった。このような廓清術は当然，大 動脈周囲に存在する交感神経系の損傷を高頻度に若起 し，術後の射精障害を生じてきた。しかしながら，化 学療法の進歩により進行性辠丸腫瘍の多くが完治可能 となってきた今日，青壮年男子の射精機能保存は重大 な問題である。そこで当科掞よび関連施設に打いて化 学療法を併用して後腹膜リンパ節の限局廓清を行なっ た症例について，摘除範囲，射精障害，予後を検討す るとともに，交感神経系の走行を解剖体にて検索し， それらの結果をふまえて，射精機能の保持を指向した 廓清法について言及した。

\section{対象および方法}

1977年より1986年までの10年間に東京医科歯科大 学, 埼玉がんセンター, 関東中央病院にて, 化学療法 を併用して後腹膜リンパ節の限局廓清を行なった 45 例 のらち, 死亡 4 例, 射精機能の回答を得られなかった 5 例の計 9 例を除いた，廓清後の射精機能が判明して いる36例を対象とした。 その詳細を, Table 1 に示し た. 年齢は17歳から51歳にわたり, 平均31歳であった。 腫瘍の進展度は, “睪丸腫瘍取扱い規約”1)に準拠した。
Table 1 Summary of the patients

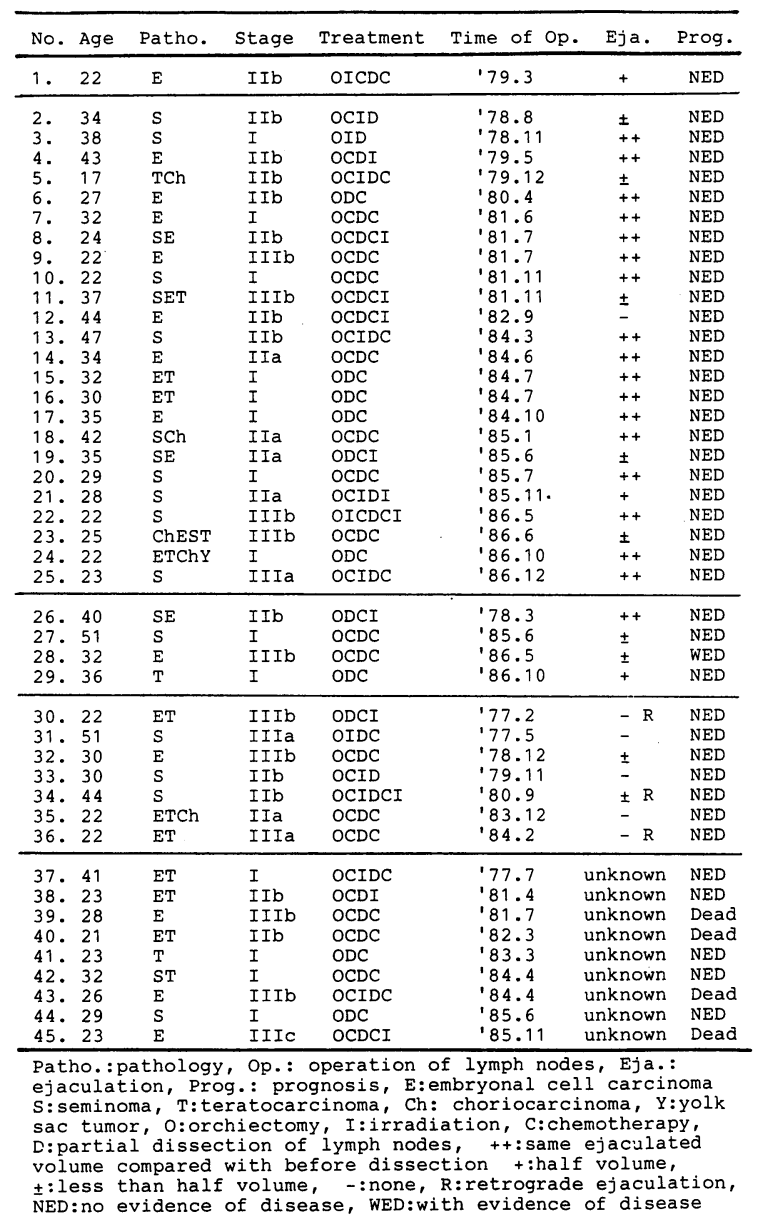


リンパ節の廓清は経腹膜的に行ない，転移巣および転 移が疑われるリンパ節とその周团脂肪組織を，血管を 残して一塊として摘出した。化学療法は症例により廓 清前, 隡清後もしくは廓清前後に行ない, 薬剤として は cis-diamminedichloroplatinum, vinblastine, bleomycin, peplomycin を用いた。廓清前に行なった 化学療法は $1 \sim 3$ コースであった。射精機能は, 精液 の射出の有無, 精液量について, 面接もしくは書面に て回答を得, 射出がないか少量の場合には, 逆行性射 精の有無を, マスターベーション後の検尿により判定 した。な抢，射精機能の判定は1987年 6 月の時点で行 なった。

Table 2 Prognosis of the patients of stage II $\sim$ III

\begin{tabular}{ccccc}
\hline \multirow{2}{*}{ Stage } & \multicolumn{3}{c}{ Prognosis } & \multirow{2}{*}{ Total } \\
\cline { 2 - 4 } & NED & WED & Dead & \\
\hline II & 17 & 0 & 1 & 18 \\
IIIa & 3 & 0 & 0 & 3 \\
IIIb & 6 & 1 & 2 & 9 \\
IIIC & 0 & 0 & 1 & 1 \\
\hline Total & 26 & 1 & 4 & 31 \\
NED: no evidence of disease & & \\
WED: & &
\end{tabular}

Table 3 Prognosis of the patients of stage II $\sim$ IIIa followed for more than two years

\begin{tabular}{cccc}
\hline \multirow{2}{*}{ Stage } & \multicolumn{2}{c}{ Prognosis } & Total \\
\cline { 2 - 4 } & NED & Dead & \\
\hline II & 15 & 1 & 16 \\
IIIa & 2 & 0 & 2 \\
\hline Total & 17 & 1 & 18 \\
NED & & &
\end{tabular}

Fig. 1 Dissected area and ejaculatory disturbance. Shaded area was dissected (Case 1).

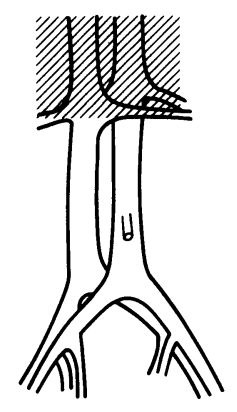

\begin{tabular}{cc}
$\begin{array}{l}\text { Volume of semen compared } \\
\text { with before dissection }\end{array}$ & $\begin{array}{l}\text { Number of } \\
\text { cases }\end{array}$ \\
\hline Half & 1 \\
\hline Total & 1
\end{tabular}

\section{結果}

1）治療成績

化学療法を併用して後腹膜リンパ節の限局廓清を行 なった45例中, Stage II 以上の症例は 31 例であった。 これらの症例の予後をTable 2 に示した. 26例が NED で， 1 例が WED で生存し，死亡は 4 例であっ た。死亡例の内， 3 例は藏器転移を有する Stage IIIb 以上の症例であり, Stage II で死亡した 1 例 (Case 40) はリンパ節転移巣の摘出重量が $3 \mathrm{~kg}$ の症例であった。 2 年以上経過観察を行なったリンパ節転移のみの 18 例 （Stage II～IIIa）について，その予後をみると，Case 40以外はすべて NED で生存していた（Table 3).

2) リンパ節の摘除範囲と射精障害

リンパ節の摘除範囲と射精障害との関係を以下の 4 群に分けて検討した。

i ）腎血管部より上部の摘除：Case 1 (Fig. 1)

腎血管部より上部の女を摘除した症例は 1 例であっ たが, 精液の射出が認められ, 精液量は術前の約半量 であった。

ii）腎血管部より下腸間膜動脈起始部周囲までの摘 除: Case 2 25 (Fig. 2)

Fig. 2 の範囲の摘除を行なった症例は24例である. しかしながら全例が Fig. 2 の全ての範囲を摘除した のではなく, 症例によってはこの範囲の 1 部を摘除し ている. その詳細を Table 4 に示す. 24例の内, 23例 には精液の射出が認められ，射出のなかったのは 1 例 のみ（Case 12）であった。射出のあった23例の精液量 については, 術前とほぼ同量が17例, 約半量が 1 例,

Fig. 2 Dissected area and ejaculatory disturbance. Shaded area was dissected (Case 2 25).
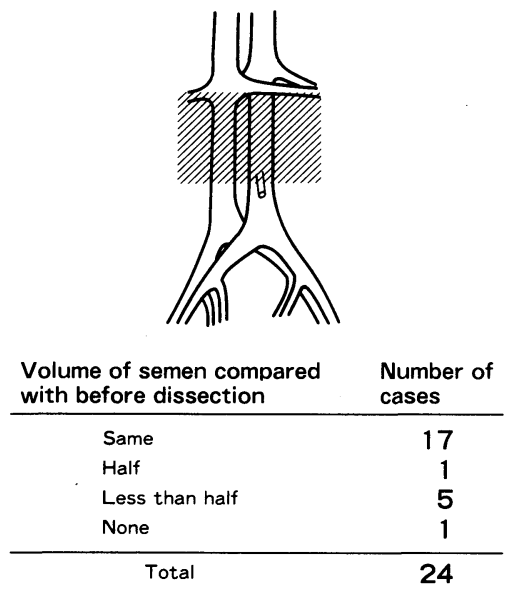
Table 4 Dissected area in the upper portion of inferior mesenteric artery

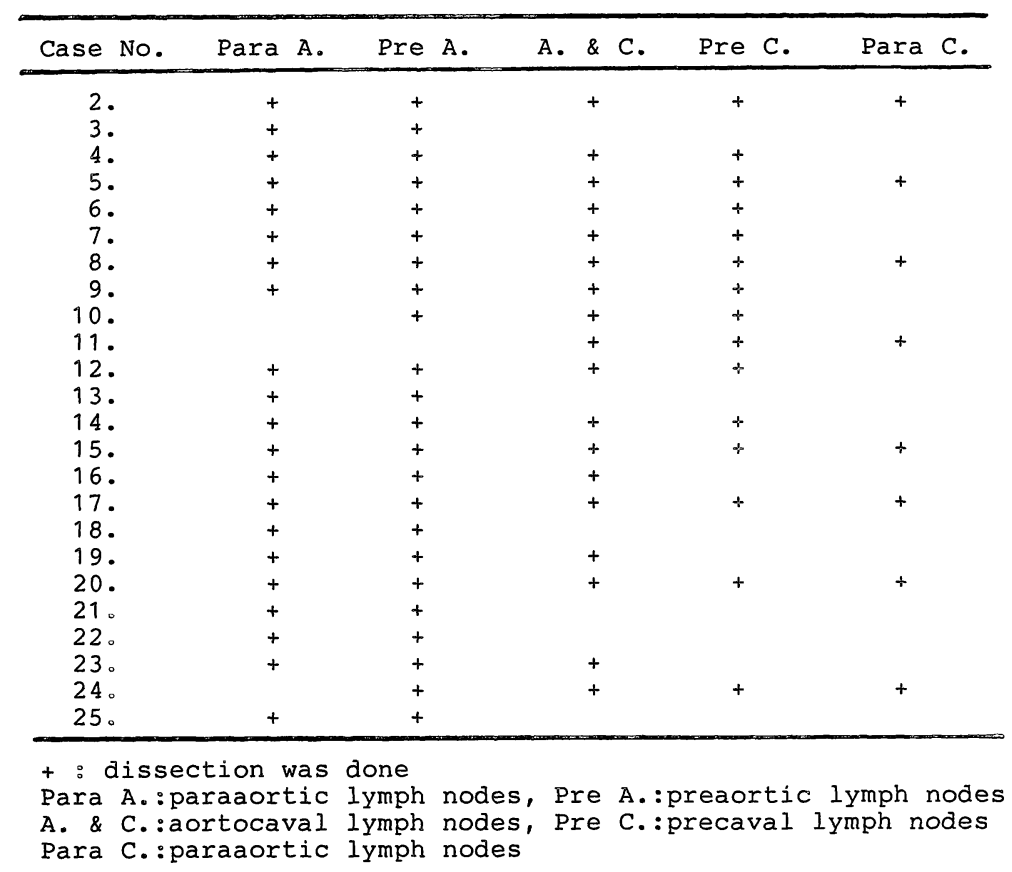

Fig. 3 Dissected area and ejaculatory disturbance.

Shaded area was dissected (Case 26 29).
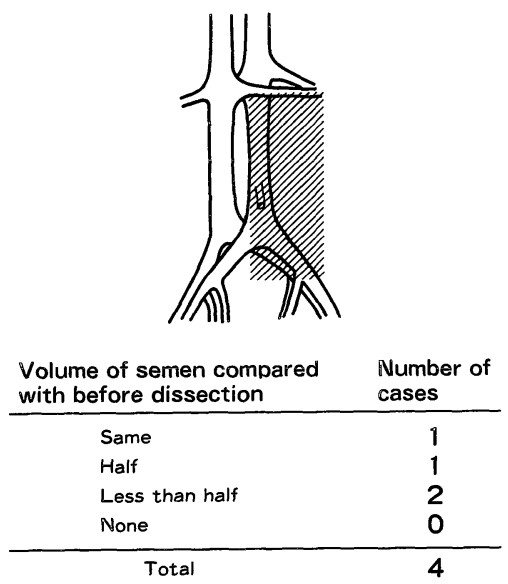

半量以下が 5 例であった。なお Case 8は限局廓清後結 婚し，子供を得ている。

iii）腎血管部より腸骨動脈部までの片側の摘除：

Case 26〜29 (Fig. 3)

この範囲の摘除では，4例全例に射出が認められた が, 精液量は同量が 1 例，半量が 1 例，半量以下が 2 例であった。

iv）腎血管部より腸骨動脈部までの両側の摘除：
Fig. 4 Dissected area and ejaculatory disturbance. Shaded area was dissected (Case 30 36).
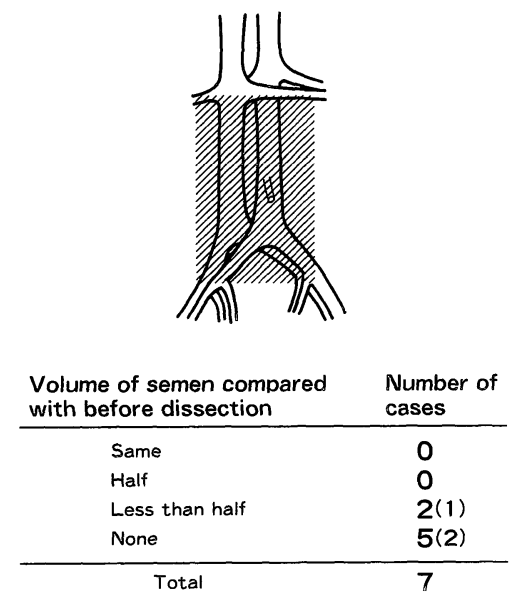

( ) : retrograde ejaculation

Case 30 36 (Fig. 4)

大動脈の分岐部を含んだ両側の摘除では，7例中 5 例に精液の射出がなく，射出のある 2 例も極く少量で あった。この 7 例のらち, 逆行性射精の有無を検索で きたのは 4 例であったが， $5 ち 3$ 例に逆行性射精が認 められた. Case 36の廓清前後の所見を Fig. 5，6に示 す。本例は外腸骨リンパ節から鎖骨上リンパ節まで転 
Fig. 5A Lymphangiography before dissection (P.A view)

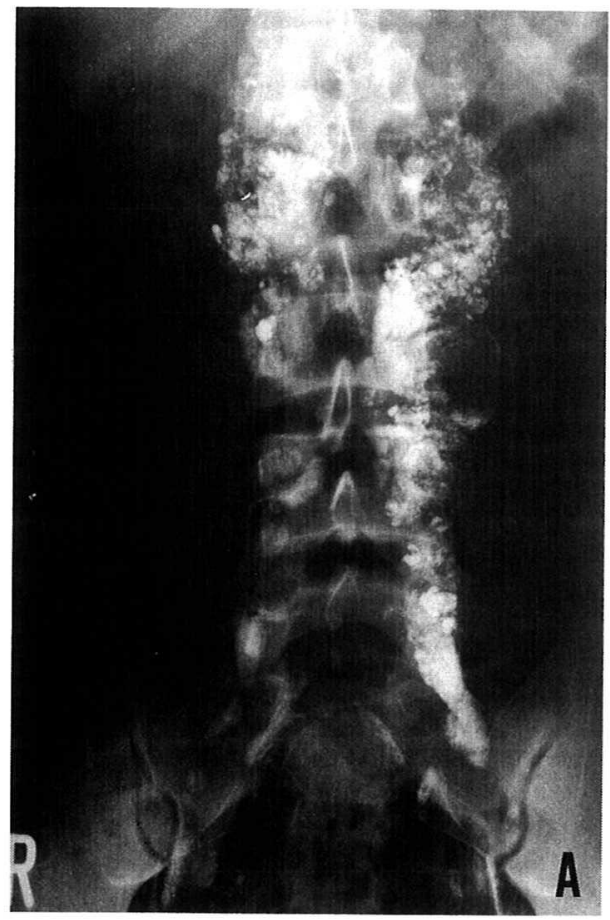

Fig. 5B Lymphangiography before dissection (lateral view)

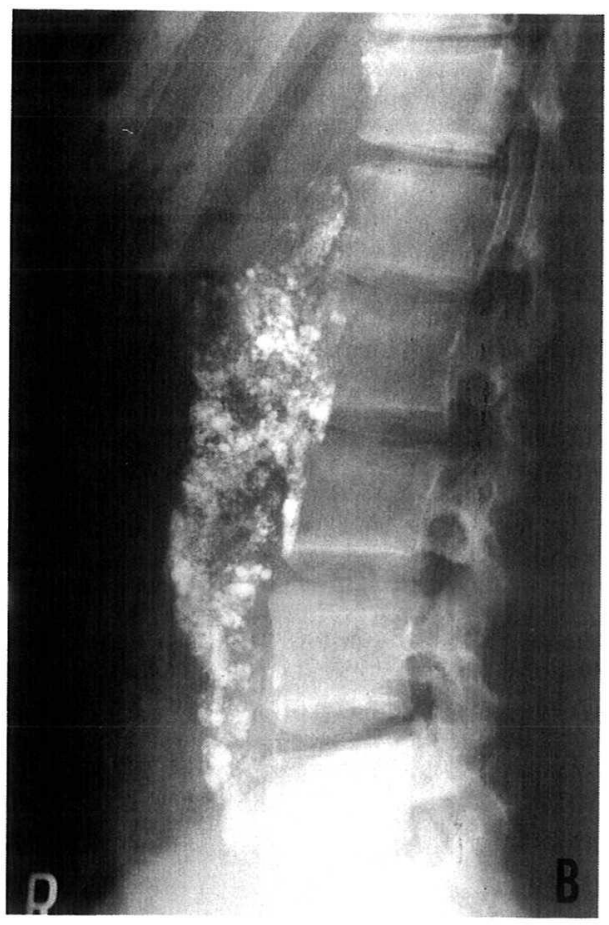

移のあった Stage IIIa の症例であり, 転移部位をすべ て廓清した。術後 4 年 3 カ月を経過した現在, 再発の 微候なく，消防士として勤務している。しかしながら 両側広沉廓清のため逆行性射精である。

3）交感神経系の剝離

東京医科歯科大学第 2 解剖学教室の解剖体を使わせ て頂き, 後腹膜リンパ節廓清部位の交感神経系を剝離 した（Fig．7，8）。大動脈周囲の交感神経系をみると， まず大動脈分岐部に上下腹神経叢が認められ，これよ り骨盤内へ 2 本の下腹神経が続いている。この神経叢 の上方からは, 大動脈前壁に沿って下降してきた線維 群が合流し, 側方からは, 左右の交感神経節から出た 線維群 (側方線維群) が合流する。右側では交感神経 幹は大静脈の外側に沿い下降し, 腰静脈がその上を横 断している。側方線維群は交感神経節から出て, 大静 脈の裏を通って大動脈の側壁へ向い, 大動脈分岐部で 上下腹神経叢合流する。左側では, 交感神経幹は大 動脈の外側で, リンパ節群の内背側を下降しており, 側方線維群は交感神経節から出て,リンパ節群を貫き, 大動脈側壁へ向い，上下腹神経叢に合流している。

Fig. 6A Plain X-ray film of abdomen after dissection

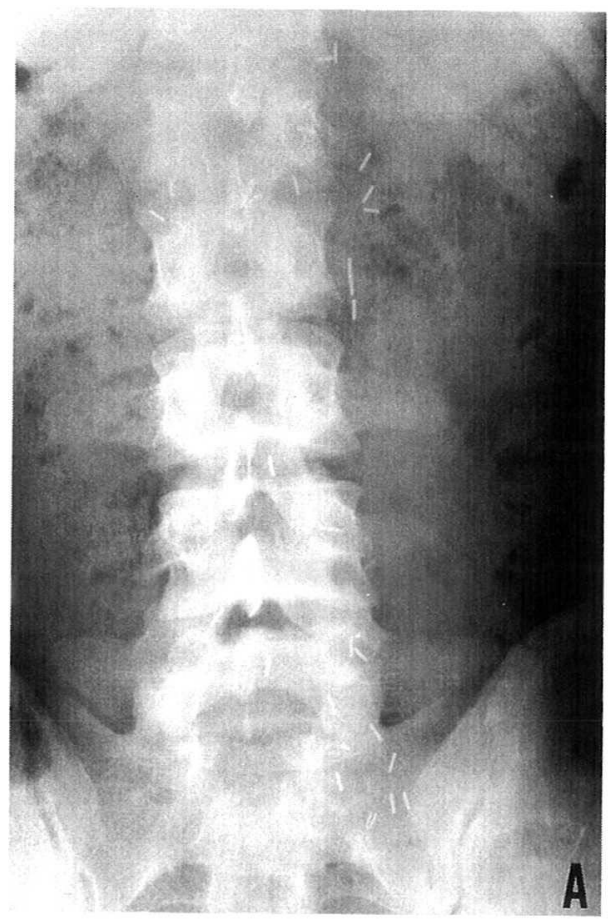


Fig. 6B Dissected lymph nodes

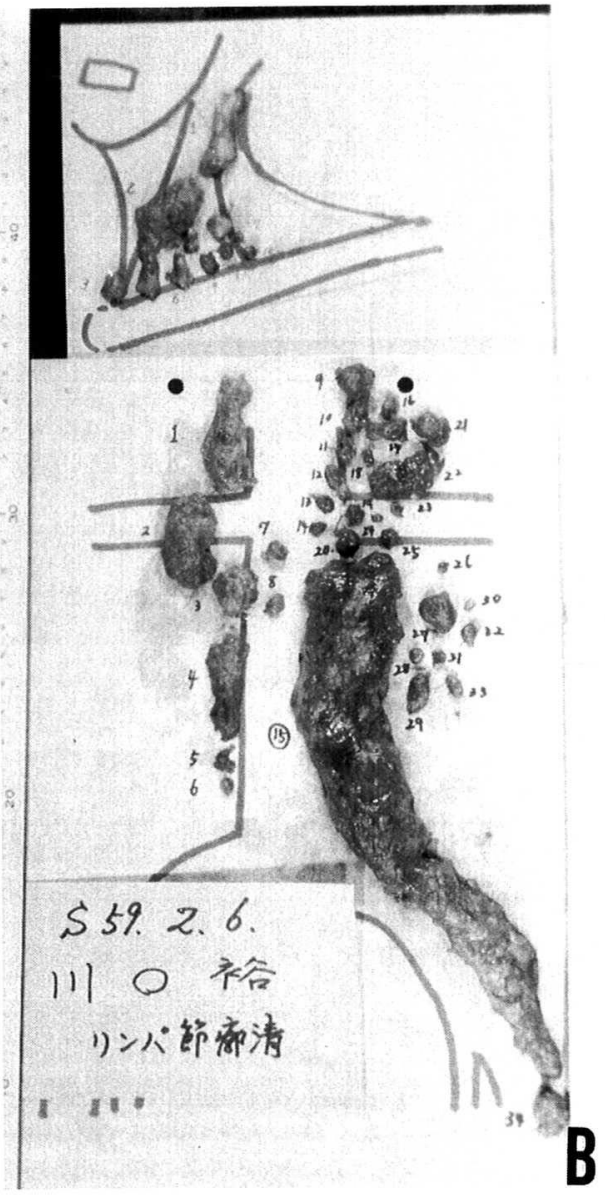

考 察

射精を惹起する交感神経系は Fig. 92)に示す如く， 大動脈，腸骨動脈周囲に存在するが，リンパ系もこれ らの血管に沿って存在するため, リンパ節廓清後に射 精障害を生じた例が多数報告されている。これまで両 側の広沉廓清では, emission 消失もしくは逆行性射精 を生ずるのが普通であるといわれ，Kedia ら³ は36例 中35例に, Fossa ら ${ }^{4)}$ は61例中51例に, Fritz $ら^{5)}$ は87例 中64例にdry ejaculation を生じたと報告しており, 本 邦でも河合ら ${ }^{6}$, 高崎ら 全例に, emission 消失を認めている.

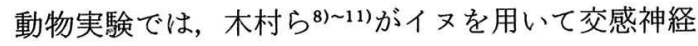
系の損傷部位と射精障害との関係を検討している。

Fig. 10, Table 5 に射精の伝導路の模式図と木村らの 実験結果を示した。骨盤内の 2 本の下腹神経は上下膜 神経叢に由来しており, この上下復神経叢は, 上方よ
Fig. 7 Right lateral sympathetic nerves and sympathetic cord. A : lateral sympathetic nerve, B: ganglion, $\mathrm{C}$ : sympathetic cord, D : aorta, $\mathrm{E}$ : vena cava inferior, $\mathrm{F}$ : lumbar vein on the cord.

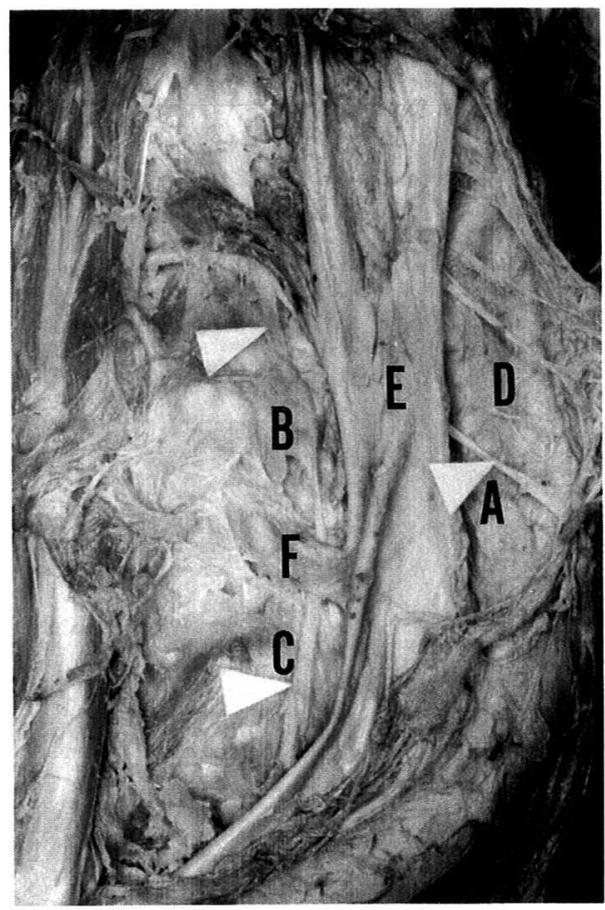

り大動脈壁に沿い下降してくる線維群（中央線維群） と, 側方の交感神経節から直接合流する線維群（側方 線維群）の 2 つの線維群から構成されている. 中央線 維群を電気刺激すると, emissionが起こるが, この線 維群を切断しても正常の射出が起こる. また側方線維 群を刺激すると emission は起こらず, 内尿道口が閉鎖 し，これを切断すると内尿道口が閉鎖せず，逆行性射 精となる、下腹神経を刺激すると emission と内尿道口 閉鎖が扣こり，切断するとやはり逆行性射精となる。 つまり emission 自体は Fig. 10 の A, B，Cの経路が 切断されても温存されるとしており, 内尿道口閉鎖機 能を担っているのは側方線維群であるとしている. 本 論文ではヒトについて交感神経系の損傷部位と射精障 害との関係をみたが, その結果はイヌでの実験結果に 良く一致していた。つまり, 腎血管部より上部扣よび 腎血管部から下腸間膜動脈起始部周囲までのリンパ節 摘除では, 精液の射出が認められ, emission, 内尿道 口閉鎖機能のいずれも保存されていた。一方, 腎血管 部から腸骨血管部に至る摘除では, 半側の場合はほぼ 
Fig. 8 Left lateral sympathetic nerves and sympathetic cord. A: lateral sympathetic nerve, B: ganglion, $\mathrm{C}$ : sympathetic cord, D: aorta, E: big bundle of superior hypogastric plexus, $\mathrm{F}$ : lymph nodes on the lateral nerve.

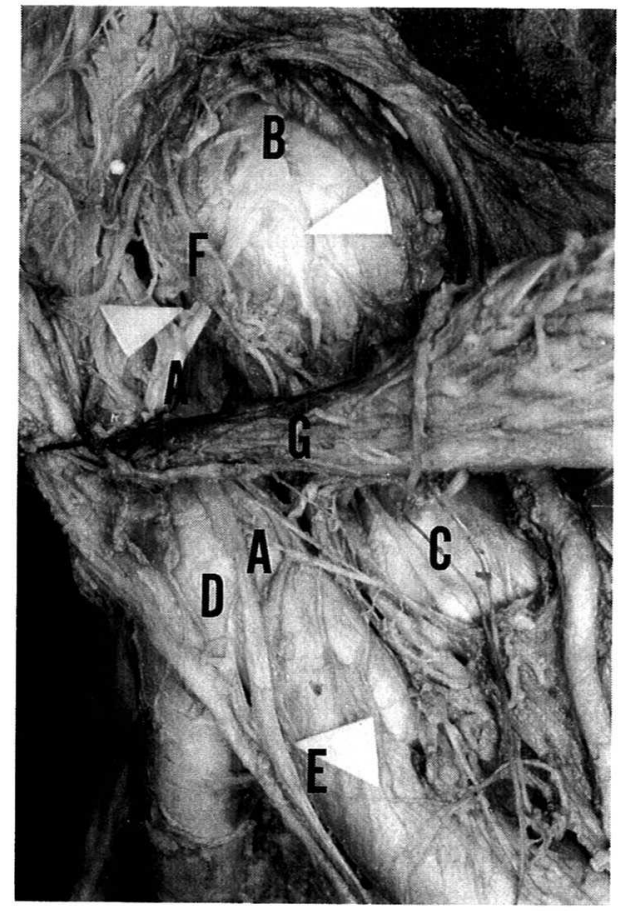

射出機能は保たれ, 両側の場合は射出の消失する例が 多く，その中には逆行性射精が多く認められた。この ように動物実験およびヒトでの結果より，逆行性射精 を防ぐためには，上下腹神経叢を保存すること，扣よ び側方線維群を少なくとも 1 側は保存することが肝要 であると考えられる。

実際の手術に際して，これらの神経を保存するため の具体的な方法として, 以下の操作がすすめられる。 Fig. 11 は東京医科歯科大学第 2 解剖学教室の佐藤ら
Fig. 9 Sympathetic nerve system

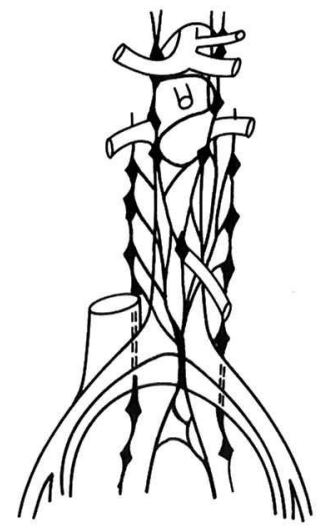

Fig. 10 Sympathetic pathways in the area of retroperitoneal lymph node dissection

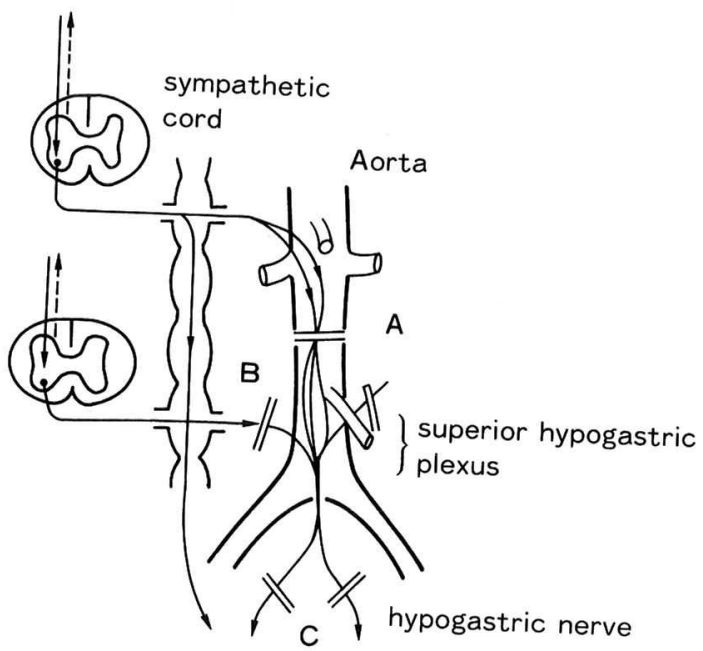

が行なった33体の上下腹神経叢の解剖結果をまとめた ものであるが, 大動脈分岐部に幅約 $5 \mathrm{~mm}$, 長さ約 $4 \mathrm{~cm}$ の線維束があり,上方へ左右約 $2 \mathrm{~mm}$ の側方線維が認め

Table 5 Results of electorical stimulation and section of sympathetic nerves in the animal experiment

\begin{tabular}{ccc}
\hline location & electorical stimulation & section \\
\hline A & emission & normal ejaculation \\
B & $\begin{array}{l}\text { closure of internal } \\
\text { urethral orifice }\end{array}$ & retrograde ejaculation \\
C & $\begin{array}{l}\text { emission \& closure } \\
\text { of internal urethral } \\
\text { orifice }\end{array}$ & retrograde ejaculation \\
\hline
\end{tabular}

Kimura et al. 1971 
Fig. 11 Diagram of superior hypogastric plexus (by K. Sato)

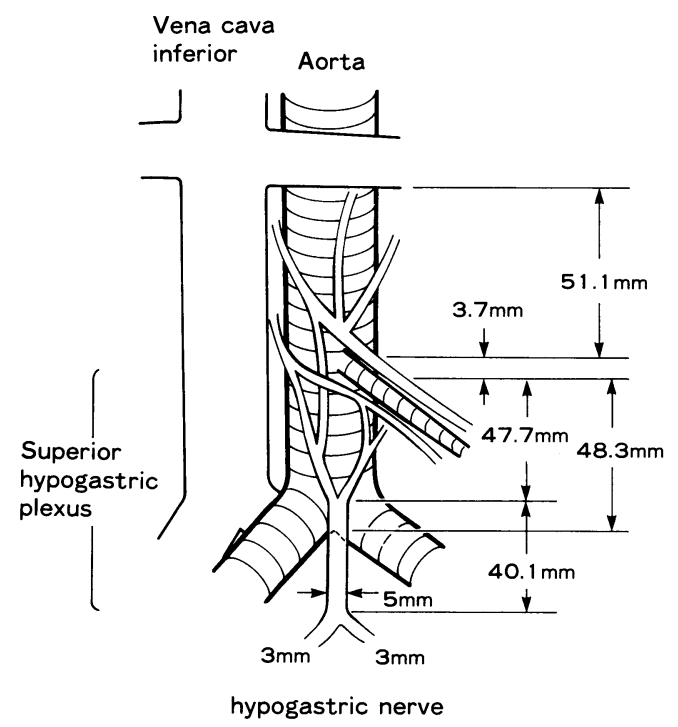

られる.この図は最も太い側方線維を示したもので, 細い線維を含めると実際には何本もあり，大動脈分岐 部では動脈の後面を回って神経束に合流する線維も認 められる，手術時には，まず大動脈分岐部を確認し， この部で腹膜後葉を切開し, 分岐部上を縦に走る太い 神経束を周囲の脂肪織から剥離する．次いでこの神経 束を持ち上げ, 上方へたどり左右の側方線維を剥離し， 少なくとも片側の側方線維を温存する方法が最良と思 われる。

一方, 従来, 交感神経節を損傷すると emission の消 失する例が知られており，末梢血管拡張の目的で行な われる交感神経節切除後などに，射精障害が報告され ている. Whitelaw ら ${ }^{12)}$ は $\mathrm{L}_{1}$ から $\mathrm{L}_{3}$ までの両側の節切 除で54\%に, Smithwick ら ${ }^{13}$ ) $\mathrm{L}_{2}$ の両側の節切除で $100 \%$ に，片側の節切除で $50 \%$ に emission 消失を認め て和り, 本邦でも宮崎ら $\left.{ }^{14}\right)$ が $\mathrm{L}_{2}$ から $\mathrm{L}_{4}$ の片側節切除 で $42 \%$ emission 消失を報告している。これらのこと から交感神経節を含む交感神経幹を温存することが, emission を保存するためには重要であると考えられ る. 下腸間膜動脈起始部より上方の摘除で dry ejaculation となった症例や，広沉廓清で逆行性射精もなく なった症例などは，交感神経幹を損傷した可能性も考 えられる。この神経幹の損傷を防ぐためには, 交感神 経系の剝離の項で述べた走行に留意して，まずこの神 経幹を剝離してからリンパ節の摘除を行ならのも 1 法
かと思われる。

化学療法が著効を示すようになった今日, 欧米でも 廓清範囲を縮小する傾向にあり，片側廓清では射精障 害は著明に減少すると報告されている。片側廓清で Fritz ら ${ }^{5)}$ は37例中 8 例に, Fossa ら ${ }^{4)}$ は21例中 7 例に, Pizzocaro ら ${ }^{15)}$ は61例中11例にdry ejaculation 認 めている，片側廓清でも射精障害は少なからず生じて おり，手術時にはこれまで述べた注意が同様に必要で あると思われる。

患者の予後を悪化させずに, 機能障害を最小限に抑 える手術が最良であるが, 本報の如く, 化学療法を併 用して，転移巣および転移が疑われるリンパ節とその 周囲脂肪組織に, 摘除範囲を限定しても, 予後に悪影 響はなかった。進行性辠丸腫瘍の多くが完治可能と なってきた今日，化学療法を併用して廓清範囲を縮小 するとともに，神経の温存を意困した廓清を行ない， 青壮年男子の射精機能を保存するよう努力すべきであ ろう。

\section{結語}

1）化学療法を併用して後腹膜 リンパ節の限局廓清 を行なった 45 症例について摘除範囲, 予後を検討し, 内36例で射精障害を検索した。

2）化学療法を併用することにより, 摘除範囲を転移 部位もしくは転移が疑われる部位に縮小しても予後に 対する悪影響はなかった。

3）本手術で見られる射精障害は, emission 消失か 逆行性射精であった。

4) 大動脈前壁に沿い下降する交感神経線維は下腸 間膜動脈起始部より上位では, 切除しても射精機能は 保たれた。

5) 大動脈分岐部周辺の両側摘除では, dry ejaculation を生じたが，片側摘除では生じなかった。前者の 例では逆行性射精が認められた。

6）大動脈壁に沿ら交感神経線維の損傷範囲が腎血 管部から腸骨血管部に及んでも, 左右交感神経幹が温 存されたと思われる症例では emission は保たれた。

7）化学療法が著明な奏効率を示す今日, 化学療法の 併用を考虑に入れ, 青壮年男子の射精機能の温存を意 図したリンパ節廓清を行ならべきであろう。

本論文の要旨は第 52 回日本泌尿器科学会東部総会にて発 表した。

稿を終えるに当たり, 交感神経の解剖に関して種々御教 示下さった本学第 2 解剖学教室佐藤達夫教授, 佐藤健次講 師に深謝致します。 


\section{文献}

1) 日本泌尿器科学会, 日本病理学会編 : 泌尿器科・病 理, 辠丸腫瘍取扱規約. 金原出版, 東京, 1980 .

2) Weinstein, B.B.: The surgical anatomy of the superior hypogastric plexus: With a report of 150 personal dissections. Surg. Gynec. \& Obst., 74, 245-255, 1942.

3) Kedia, K.R., Markland, C. and Fraley, E.E. : Sexual function following high retroperitoneal lymphadenectomy. J. Urol., 114, 237-239, 1975.

4) Fossa, S.D., Ous, S., Abyholm, T. and Loeb, M. : Post-treatment fertility in patients with testicular cancer: I. Influence of retroperitoneal lymph node dissection on ejaculatory potency. British J. Urol., 57, 204-209, 1985.

5) Fritz, K. and Weissbach, L.: Sperm parameters and ejaculation before and after operative treatment of patients with germ-cell testicular cancer. Fertil. Steril., 43, 451-454, 1985.

6) 河合恒雄, 井田時雄, 森田 上, 古畑哲彦: 冝丸腫 瘍における後腹膜リンパ節郭清術後の emission 消失について，日泌尿会誌，63，906-911，1972.

7）高崎 登, 出村 愰, 沼田正紀：睪丸腫瘍における 後腹膜リンパ節郭清術. 泌尿紀要, $21,631-643$, 1975 .

8）木村行雄: 射精の研究. 第 1 報. 射精と末梢支配神
経について一後部尿道圧曲線を中心にして，日泌 尿会誌, 61，284-295，1970。

9）木村行雄, 宮田宏洋, 安達国昭 : 射精の研究. 第 3 報. 精液の emission と射精時に拈ける内尿道口の 閉鎖の支配神経について（I），日泌尿会誌，62， 877-886, 1971 .

10）木村行雄, 宮田宏洋, 安達国昭: 射精の研究. 第 4 報。精液の emissiojn と射精時における内尿道口 の閉鎖の支配神経について(II). 日泌尿会誌，63， $343-345,1972$.

11）木村行雄：射精のメカニズム. 臨泌，34, 103-116, 1980.

12) Whitelaw, G.P. and Smithwick, R.H.: Some secondary effects of sympathetectomy. New England J. Med., 245, 121-130, 1951.

13) Smithwick, R.H.: An evaluation of the surgical treatment of hypertension. Bull New York Acad. Med., 25, 698-716, 1949.

14）宮崎一興, 鈴木正泰, 石堂哲郎：手術後の性機能障 害. 手術, 36, 1277-1286, 1982.

15) Pizzacaro, G., Salvioni, R. and Zanoni, F.: Unilateral lymphadenectomy in intraoperative stage I nonseminomatous germinal testis cancer. J. Urol., 134, 485-489, 1985.

(1988年 8 月 1 日受理) 